\title{
Research Article \\ Effect of scion varieties and wrapping materials on success of tongue grafting in Kiwifruit (Actinidia deliciosa) in Dolakha, Nepal
}

\author{
${ }^{1}$ Divya Pandey ${ }^{*},{ }^{2}$ Bishal Shrestha, ${ }^{1}$ Madan Sapkota and ${ }^{1}$ Sarita Banjade \\ ${ }^{1}$ Agriculture and Forestry University, Rampur, Chitwan, Nepal \\ ${ }^{2}$ Department of Horticulture, Agriculture and Forestry University, Rampur, Chitwan, Nepal \\ *Correspondence: divyaa.pandeyy@gmail.com \\ ORCID ID: https://orcid.org/0000-0003-4862-5045
}

Received: August 02; Accepted: October 12; Published: October 25, 2019

(C) Copyright: Pandey et al. (2019).

(c) (i) (8)

This work is licensed under a Creative Commons Attribution-NonCommercial 4.0 International License.

\begin{abstract}
This study was conducted at Boch, Bhimeshwor-8, Dolakha, Nepal from January to May, 2019 to study the effect of scion variety and wrapping materials on growth performance of kiwi seedling rootstock. The field experiment was carried out in Factorial Randomized Complete Block Design using four replications. The treatments consisted of four scion varieties (Monty, Bruno, Hayward, Allison) grafted onto one year old kiwi seedling (Actinidia deliciosa) and two types of wrapping material (Grafting tape and Polyethylene plastic). The measured traits included sprout length, diameter, number of leaves, and number of sprouted bud per graft, graft success, mortality and survival percentage of grafts. The success rate of kiwi grafting was significantly affected by the scion variety and the wrapping materials. Allison variety showed the minimum days (61.72 days) to first sprouting and the maximum length of sprouts, diameter, number of leaves and number of sprouted bud per graft at the final observation. Monty variety showed the lowest growth performance. The maximum graft success (96.87\%) and survival percentage of grafts (93.75\%) was observed in Allison variety statistically at par with Bruno and Hayward and the lowest graft success(73.44\%) and survivability(64.21\%) was observed in Monty due to high mortality of the sprouted grafts. Grafting tape was superior to polyethylene plastic in terms of days to first sprouting (64.08 days), number of sprouted buds per grafts, number of leaves, graft success $(92.18 \%)$ and survival of the grafts $(87.01 \%)$ at the final observation. Interactive effect was found non-significant. In a nutshell, Allison is the best scion variety for grafting under the climatic condition of Dolakha and the grafting tape was the suitable tying material.
\end{abstract}

Keywords: Kiwifruit, grafting, graft success, variety, wrapping materials

Correct citation: Pandey, D., Shrestha, B., Sapkota, M., \& Banjade, S. (2019).Effect of scion varieties and wrapping materials on success of tongue grafting in Kiwifruit (Actinidia deliciosa) in Dolakha, Nepal. Journal of Agriculture and Natural Resources, 2(1), 180-192 
Journal of Agriculture and Natural Resources (2019) 2(1): 180-192

ISSN: 2661-6270 (Print), ISSN: 2661-6289 (Online)

DOI: https://doi.org/10.3126/janr.v2i1.26065

\section{INTRODUCTION}

Kiwifruit is a dioecious vine, belonging to family Actinidiaceae and genus Actinidia with basic chromosome no $2 \mathrm{n}=58$ (Crowhurst et al.,1992). The fruit is rich in vitamin $\mathrm{C}$ and contains relevant levels of dietary fibre, potassium, vitamin E, folate, antioxidants and many other bioactive compounds (Richardson et al., 2018). Kiwifruit, being native to China was also called Chinese gooseberry and plants were introduced into New Zealand in the early 1900s, which subsequently became the world's largest exporter of kiwifruit (Morton, 2011). The top 10 producing countries in the world are China, Italy, New Zealand, Chile, Greece, France, Turkey, Iran, Japan and United States and they produce more than 1.37 million tons of kiwifruit (FAOSTAT, 2013/2014). The total area, productive area, production and yield of Kiwifruit in Nepal are 551 ha, 186 ha, $719 \mathrm{mt}$ and $4 \mathrm{mt} / \mathrm{ha}$ respectively while that of Dolakha are $185 \mathrm{ha}, 60 \mathrm{ha}, 330 \mathrm{mt}$ and $5.5 \mathrm{mt} / \mathrm{ha}$ respectively (MOAD, 2016/17). Two main species of kiwifruit are grown throughout the world: Actinidia deliciosa and Actinidia chinensis. Actinidia deliciosa includes cultivars like Hayward long, Hayward round, Abbot, Allison, Bruno and Monty while Actinidia chinensis includes Red Kiwi, Hort 16, Golden Kiwi (Dhakal 2018; Sims,2011).

Asexual method, particularly tongue grafting is suitable for kiwifruit propagation (Mohammadi, J.,\& Abdi, M., 1993). Rootstock and scion influence various growth parameters and pomological traits of grafted plants such as height, leaves, growth habit of the tree, time of fruit maturity and yield. After grafting, graft union is tied to promote healing and preventing drying of buds and scion which can be done in different ways (Hartman et al., 2007). Soft tying materials prevent humidity loss and prevent the drying of scion, as a result of which wound tissue over the cut surface could be produced more easily for healing and cambial connectivity between stock and scion set rapidly (Zenginbal et al., 2006).

Despite the escalating demand of the saplings for the commercial production, farmers usually face the problem of low graft success, which is huge loss to the kiwifruit growers. Suitable varietal identification for a particular domain/area with appropriate wrapping materials to prevent moisture desiccation is a key to achieve higher success rate. Graft incompatibility due to improper varietal selection could be the reason for graft failure. The objective of this experiment was to study the effect of different varieties of scion and tying materials on success rate and growth parameters of Kiwifruit under Dolakha condition.

\section{MATERIALS AND METHODS Experimental Site}

The research was conducted at Temperate Fruits Rootstock Development Centre,Boch, Bhimeshwor-8, Dolakha from January 21 to May 21, 2019. The site is located at an altitude of 1975 meter above sea level and $11 \mathrm{~km}$ west of Charikot within $27^{\circ} 28^{\prime}-28^{\circ} 0^{\prime} \mathrm{N}$ latitude and $85^{\circ} 50^{\prime}-86^{\circ} 32^{\prime}$ E longitudes (DADO, Dolakha, 2016). The area is characterized by temperate climate with frost free winter season. 
Journal of Agriculture and Natural Resources (2019) 2(1): 180-192

ISSN: 2661-6270 (Print), ISSN: 2661-6289 (Online)

DOI: https://doi.org/10.3126/janr.v2i1.26065

\section{Climatic Data}

The average annual temperature is $14.7^{\circ} \mathrm{C}$ and average annual rainfall is $2091 \mathrm{~mm}$. The meteorological information on maximum, minimum and average temperature was recorded from Temperate Fruits Rootstock Development Centre.

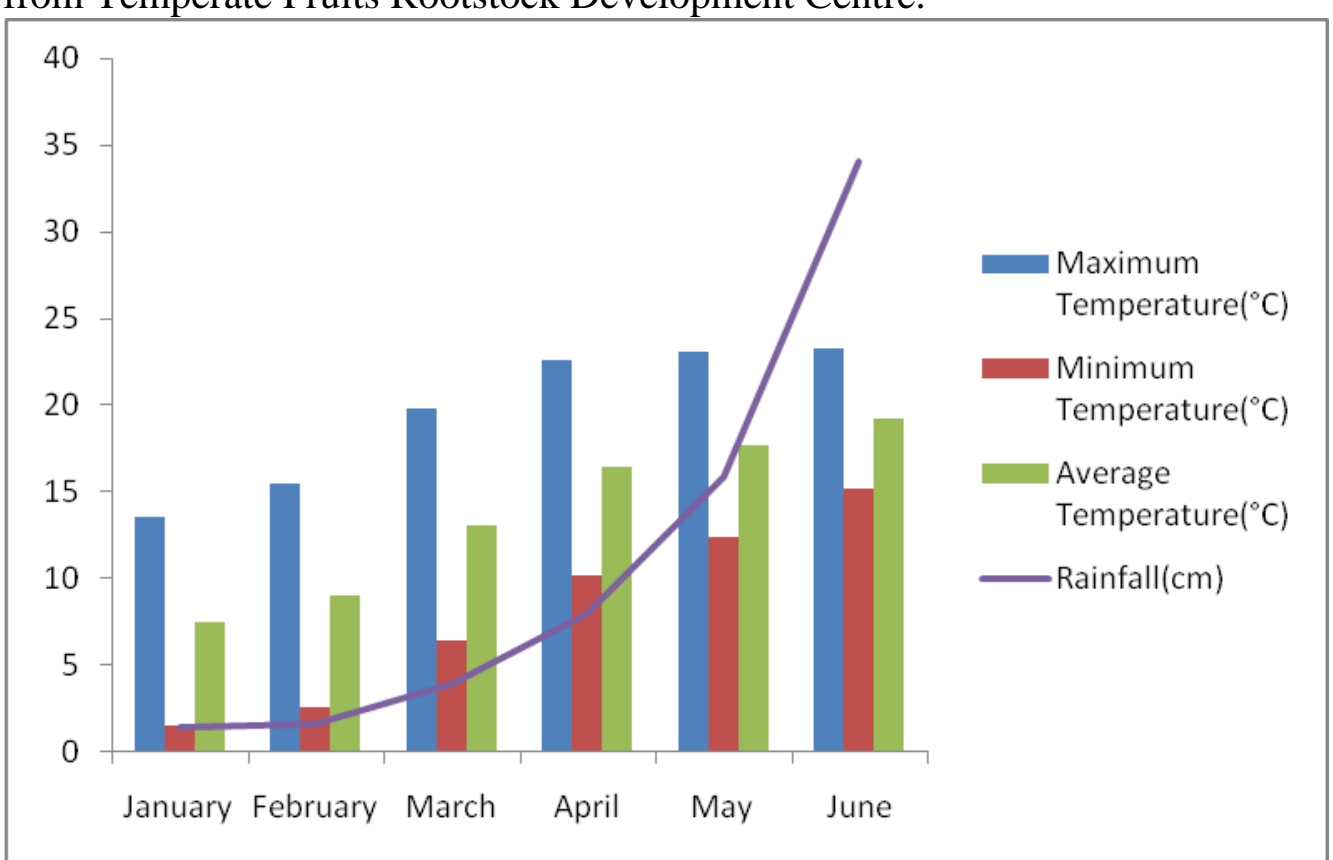

Figure 1: Average monthly temperature and total rainfall of Dolakha district (2019)

\section{Experimental Materials}

One year old disease-free rootstocks were uprooted and four varieties of scion, one year old terminal shoots ranging from 0.6 to $0.8 \mathrm{~cm}$ in diameter and $10 \mathrm{~cm}$ long and having 2 buds each were collected from the Temperate Fruits Rootstock Development Centre, Boch. The operation of tongue grafting was performed as bench grafting at January 21, 2019 and tied with two different types of wrapping materials. The grafts were placed under callus house having restricted light and regulated temperature to enhance callus initiation for 2 months and transplanted in the main field.

\section{Experimental Design}

The experiment was laid out in $4 \times 2$ factorial Randomized Complete Block Design (RCBD) designed for heterogeneous field condition.

Factor A: Scion Variety

$\mathrm{V}_{1=}$ Monty, $\mathrm{V}_{2}=$ Bruno, $\mathrm{V}_{3}=$ Hayward and $\mathrm{V}_{4}=$ Allison

Factor B: Wrapping materials

$\mathrm{W}_{1}=$ Grafting Tape and $\mathrm{W}_{2}=$ Polyethylene Plastic 
Journal of Agriculture and Natural Resources (2019) 2(1): 180-192

ISSN: 2661-6270 (Print), ISSN: 2661-6289 (Online)

DOI: https://doi.org/10.3126/janr.v2i1.26065

. The experimental field was divided into four replication unit; each replication was divided into 8 plots. The size of each plot was $0.18 \mathrm{~m}^{2}$ with an alley of $25 \mathrm{~cm}$ in between to provide space for intercultural operation. The grafts were laid out randomly in each plot in each replication with spacing of $15 \mathrm{~cm} * 15 \mathrm{~cm}$.

\section{Data collection}

To measure the growth parameters, five sample plants were taken from the central part of the plot to minimize error due to border effect

Days taken to first sprouting: The days taken to first sprouting in each treatment was recorded from the date of grafting to date of first sprout.

Average length of sprout (cm): The length of sprouts $(\mathrm{cm})$ was measured in each treatment with the help of scale in each tagged grafted plants at 75 days of grafting and at fortnight interval.

Average diameter of sprout ( $\mathbf{m m})$ : The diameter of selected sprout was measured in millimetre by vernier calliper at 15 days interval.

Average number of leaves: The total number of leaves was counted on newly emerged shoots of graft at 15 days interval.

Number of sprouted buds per graft: Each scion having 2 buds were selected for grafting. The total number of sprouted buds per graft was counted at 75 days after grafting and at 130 days after grafting.

Percentage of graft success (\%): The percentage of graft success was recorded in each treatment at 4 to 5 months after grafting with the help of following formula:

Graft success percentage $=\frac{\text { No.of sprouted grafts }}{\text { Total grafted plants }} * 100$

Percentage of Dead grafts after sprouting (\%): The total number of dead grafts after the sprouting was recorded in each treatment at 4 to 5 months after grafting and percentage of dead grafts after sprouting was calculated as:

Dead grafts after sprouting $\%=\frac{\text { Number of dead grafts after sprouting }}{\text { Total number of successful grafts }} \times 100$

Survival percentage (\%): The total number of successfully sprouted scion after deducting the mortality of sprouted grafts will be recorded and survival percentage will be calculated as: 
Journal of Agriculture and Natural Resources (2019) 2(1): 180-192

ISSN: 2661-6270 (Print), ISSN: 2661-6289 (Online)

DOI: https://doi.org/10.3126/janr.v2i1.26065

Survival $\%=\frac{\text { Total number of sprouted scion }- \text { Dead grafts after sprouting }}{\text { Total number of } \text { sprouted scion }} \times 100$

\section{Statistical Aanalysis}

The collected data was compiled by using the Ms-excel program and subjected to analysis of variance as per the procedures given in R-Studio statistical computer package for the randomized block design. Duncan's Multiple Range Test (DMRT) for mean separations was done from the reference of Gomez and Gomez (1984). The significant differences between genotypes were determined using least significant difference (LSD) test at probability level of $0.001,0.01$ or 0.05 where the effects of the treatments were significant at $0.1,1 \%$ or $5 \%$ level of probability, respectively (Gomez \& Gomez, 1984; Sharma et al., 2016; Shrestha, 2019; Jan et al. 2009; Kandel \& Shrestha, 2019).

\section{RESULTS AND DISCUSSIONS}

\section{Days to first sprouting}

Days taken to first sprouting of the grafted scions was found to be significantly influenced both by the scion variety and wrapping materials.

Table 1: Effect of Scion variety and wrapping materials on the number of days to first sprouting in Dolakha, Nepal 2019

\begin{tabular}{ll}
\hline Treatments & Days to first sprouting \\
\hline Scion Variety & \\
Monty & $64.93^{\mathrm{bc}}$ \\
Bruno & $63.49^{\mathrm{b}}$ \\
Hayward & $69.87^{\mathrm{c}}$ \\
Allison & $61.72^{\mathrm{a}}$ \\
\hline $\mathrm{SEm}( \pm)$ & 0.85 \\
$\mathrm{LSD}_{(0.05)}$ & $2.52^{* * *}$ \\
\hline Wrapping Materials & \\
Grafting Tape & $64.08^{\mathrm{a}}$ \\
Polyethylene Plastic & $65.92^{\mathrm{b}}$ \\
\hline $\mathrm{SEm}( \pm)$ & 0.607 \\
$\mathrm{LSD}(0.05)$ & $1.787^{*}$ \\
\hline $\mathrm{CV}(\%)$ & 3.74 \\
Grand Mean & 65 \\
\hline Means followed by common letter $(s)$ within columns are non-significantly different based on DMRT at P=0.05, \\
** significant at 0.01 P level, *** significant at 0.001 level, SEM: Standard error of mean, CV: Coefficient of \\
Variance
\end{tabular}

Allison variety showed the minimum days (61.72 days) to first sprouting. The maximum days (69.87 days) to sprout was recorded from the Hayward variety. According to Gotame et al.,(2016), Hayward requires high chilling requirement of 600-800 hours for vegetative bud sprouting and is a late maturing variety. Allison however has lower winter chilling requirement (250-700) hours at 32 to $45^{\circ} \mathrm{F}$ and hence had lower days to first sprouting. The variation in varieties for sprouting is due to genetical differences in translocation of food reserves and change in the cambial activity (Bose et al, 2019). 
Journal of Agriculture and Natural Resources (2019) 2(1): 180-192

ISSN: 2661-6270 (Print), ISSN: 2661-6289 (Online)

DOI: https://doi.org/10.3126/janr.v2i1.26065

The effect of wrapping materials on days to first sprouting was also found to be significantly different. The grafted scion tied with grafting tape showed minimum days (64.08 days) to first sprout. The grafted scions tied with polyethylene plastic showed significantly maximum days (65.92 days) for the first sprouting of the scion. Early sprouting in grafting tape might be due to higher elasticity which stretches more evenly and uniformly making a tighter seal. According to Hussain et al,(2016), the grafting tape prevented the desiccation of the cut surface and early callus formation that has positive effect on cambial activity at the graft union resulting in slightly faster sprouting initiation. The interactive effect of scion variety and wrapping materials on number of days taken for first sprouting was found nonsignificant.

\section{Sprout length}

At the final observation, the maximum length of sprouts was seen in Allison variety (24.55 $\mathrm{cm}$ ) making it statistically different from rest of the varieties and the minimum length was observed in Hayward variety $(16.45 \mathrm{~cm})$.

Table 2: Effect of Scion variety and wrapping materials on the average length of sprouts in Dolakha, Nepal, 2019

\begin{tabular}{|c|c|c|c|c|c|}
\hline \multirow{2}{*}{ Treatment } & \multicolumn{5}{|c|}{ Sprout length $(\mathrm{cm})$} \\
\hline & 70 DAG & $85 \mathrm{DAG}$ & $100 \mathrm{DAG}$ & $115 \mathrm{DAG}$ & $130 \mathrm{DAG}$ \\
\hline \multicolumn{6}{|l|}{ Scion Variety } \\
\hline Monty & 1.172 & $4.25^{\mathrm{b}}$ & $6.82^{\mathrm{b}}$ & $9.523^{\mathrm{b}}$ & $17.11^{\mathrm{b}}$ \\
\hline Bruno & 1.24 & $5.66^{\mathrm{a}}$ & $8.95^{\mathrm{a}}$ & $14.52^{\mathrm{a}}$ & $19.35^{\mathrm{b}}$ \\
\hline Hayward & 1.215 & $4.40^{\mathrm{b}}$ & $6.70^{\mathrm{b}}$ & $9.54^{\mathrm{b}}$ & $16.45^{\mathrm{b}}$ \\
\hline Allison & 1.26 & $5.46^{\mathrm{a}}$ & $8.69^{\mathrm{a}}$ & $14.97^{\mathrm{a}}$ & $24.55^{\mathrm{a}}$ \\
\hline $\operatorname{SEm}( \pm)$ & 0.083 & 0.28 & 0.473 & 1.13 & 1.358 \\
\hline $\operatorname{LSD}_{(0.05)}$ & $0.245 \mathrm{~ns}$ & $0.844^{* *}$ & $1.39^{* *}$ & $3.32^{* *}$ & $3.99^{* *}$ \\
\hline \multicolumn{6}{|l|}{ Wrap Materials } \\
\hline Grafting tape & 1.225 & 5.02 & 7.865 & 12.87 & 20.16 \\
\hline Polyethylene plastic & 1.218 & 4.87 & 7.72 & 11.45 & 18.57 \\
\hline $\operatorname{SEm}( \pm)$ & 0.06 & 0.203 & 0.33 & 0.799 & 0.96 \\
\hline $\operatorname{LSD}_{(0.05)}$ & $0.173 \mathrm{~ns}$ & $0.59 \mathrm{~ns}$ & $0.983 \mathrm{~ns}$ & $2.34 \mathrm{~ns}$ & $2.82 \mathrm{~ns}$ \\
\hline $\mathrm{CV}(\%)$ & 19.29 & 16.42 & 17.16 & 26.31 & 19.82 \\
\hline Grand Mean & 1.22 & 4.95 & 7.8 & 12.14 & 19.36 \\
\hline
\end{tabular}

Means followed by common letter(s) within columns are non-significantly different based on DMRT at P=0.05, ** significant at $0.01 \mathrm{P}$ level, *** significant at 0.001 level, SEM: Standard error of mean, CV: Coefficient of Variance

Varietal characters had a role in the length elongation of the sprouts. The highest length of scion noticed in Allison variety was probably due to earlier callus formation and maximum cambial continuity between rootstock and scion. Bruno showed slow increment in sprout length at the final observation due to early flowering initiation.The effect of wrapping materials on the length of sprouts was found non-significant at any of the observations. However at the final observation taken at 130 days after grafting, the length of sprouts found on grafting tape and polyethylene plastic was $20.16 \mathrm{~cm}$ and $18.57 \mathrm{~cm}$ respectively. The 
Journal of Agriculture and Natural Resources (2019) 2(1): 180-192

ISSN: 2661-6270 (Print), ISSN: 2661-6289 (Online)

DOI: https://doi.org/10.3126/janr.v2i1.26065

interaction between scion variety and wrapping material on the length of sprouts was also found non- significant at any of the observations.

\section{Average diameter of sprouted scion}

The effect of scion variety on the growth of diameter of the sprouted grafts was found significant at 85 days, 100 days and 115 days after grafting and highly significant at 130 days after grafting. At the final observation done at 130 days after grafting, the maximum diameter of the sprouted graft $(5.06 \mathrm{~mm})$ was observed in Allison variety followed by Bruno (4.85 $\mathrm{mm})$ and the lowest diameter was observed in Monty variety $(4.40 \mathrm{~mm})$. Maximum diameter in Allison might be due to getting maximum time by scion for producing more food through its leaves and excellent physiological condition. Excellent sap flow and continued food supply from stored food that enhanced graft union process resulting in higher growth in diameter of scion (Hartmann et.al, 2007). The effect of wrapping materials on the growth of the diameter of the sprouted grafts was found non-significant at each observation. Increment in diameter of sprouted scion was solely due to varietal feature and the tying materials had no role in diameter elongation. The interactive effect of scion variety and wrapping materials on diameter of sprouts was also found non- significant at any of the observations.

Table 3: Effect of scion variety and wrapping materials on average diameter of the sprouts in Dolakha, Nepal 2019

\begin{tabular}{|c|c|c|c|c|}
\hline \multirow[b]{2}{*}{ Treatments } & \multicolumn{4}{|c|}{ Average diameter of sprouted scion(mm) } \\
\hline & $85 \mathrm{DAG}$ & $100 \mathrm{DAG}$ & $115 \mathrm{DAG}$ & $130 \mathrm{DAG}$ \\
\hline \multicolumn{5}{|l|}{ Scion Variety } \\
\hline Monty & $2.72^{\mathrm{b}}$ & $3.31^{\mathrm{ab}}$ & $3.57^{\mathrm{b}}$ & $4.40^{\mathrm{b}}$ \\
\hline Bruno & $3.17^{\mathrm{ab}}$ & $3.69^{\mathrm{a}}$ & $4.1^{\mathrm{a}}$ & $4.85^{\mathrm{a}}$ \\
\hline Hayward & $2.73^{b}$ & $3.152^{\mathrm{b}}$ & $3.78^{\mathrm{ab}}$ & $4.43^{\mathrm{b}}$ \\
\hline Allison & $3.30^{\mathrm{a}}$ & $3.70^{\mathrm{a}}$ & $4.23^{\mathrm{a}}$ & $5.06^{\mathrm{a}}$ \\
\hline $\operatorname{SEm}( \pm)$ & 0.146 & 0.15 & 0.193 & 0.13 \\
\hline $\operatorname{LSD}_{(0.05)}$ & $0.43^{*}$ & $0.436^{*}$ & $0.476^{*}$ & $0.37 * *$ \\
\hline \multicolumn{5}{|l|}{ Wrap materials } \\
\hline Grafting tape & 3.07 & 3.513 & 3.97 & 4.76 \\
\hline Polyethylene plastic & 2.94 & 3.418 & 3.876 & 4.62 \\
\hline $\operatorname{SEm}( \pm)$ & 0.10 & 0.11 & 0.11 & 0.09 \\
\hline $\operatorname{LSD}_{(0.05)}$ & $0.304 \mathrm{~ns}$ & $0.324 \mathrm{~ns}$ & $0.336 \mathrm{~ns}$ & $0.264 \mathrm{~ns}$ \\
\hline $\mathrm{CV}(\%)$ & 13.90 & 12.25 & 11.67 & 7.65 \\
\hline Grand Mean & 2.978 & 3.465 & 3.922 & 4.69 \\
\hline
\end{tabular}

\section{Number of sprouted buds per graft}

Number of sprouted buds per graft is the total number of buds that is sprouted out of two buds per scion. The effect of scion variety on the number of sprouted buds per grafts was found significant both at initial and final observation i.e. at 70 days and 130 days after grafting. At 130 days after grafting, Allison had the maximum number of sprouted buds per graft (1.77) and the minimum number was observed in Monty variety (1.45). Monty showed less number at 130 days which might be due to unfavorable temperature which inhibited bud bursting and higher death of grafts. Ability of two kinds of plants to form a successful graft 
Journal of Agriculture and Natural Resources (2019) 2(1): 180-192

ISSN: 2661-6270 (Print), ISSN: 2661-6289 (Online)

DOI: https://doi.org/10.3126/janr.v2i1.26065

union is related largely to their natural relationship attributed to rapid callus formation and union of graft that led to higher bud break (Sharma, 2002).

The effect of wrapping materials on number of sprouted buds per graft was also found significant at both the observations. At the final observation i.e. at 130 days after grafting, higher number of sprouted buds per graft was observed in grafting tape (1.67) than polyethylene plastic (1.55) which may be due to the formation of earlier cambial contact between two graft components.

However, the interaction between scion variety and wrapping materials on number of sprouted buds per graft was not found significant at both the observation.

Table 4: Effect of scion variety and wrapping materials on number of sprouted buds per graft in Dolakha, Nepal 2019

\begin{tabular}{|c|c|c|}
\hline \multirow{2}{*}{ Treatments } & \multicolumn{2}{|c|}{ No. of sprouted buds per graft } \\
\hline & $70 \mathrm{DAG}$ & $130 \mathrm{DAG}$ \\
\hline \multicolumn{3}{|l|}{ Scion Variety } \\
\hline Monty & $0.725^{\mathrm{b}}$ & $1.45^{\mathrm{c}}$ \\
\hline Bruno & $0.85^{\mathrm{a}}$ & $1.65^{\mathrm{ab}}$ \\
\hline Hayward & $0.675^{\mathrm{b}}$ & $1.57^{\mathrm{bc}}$ \\
\hline Allison & $0.875^{\mathrm{a}}$ & $1.77^{\mathrm{a}}$ \\
\hline $\mathrm{SEm}( \pm)$ & 0.041 & 0.05 \\
\hline $\mathrm{LSD}_{(0.05)}$ & $0.121^{* *}$ & $0.12^{* *}$ \\
\hline \multicolumn{3}{|l|}{ Wrapping Materials } \\
\hline Grafting Tape & $0.85^{\mathrm{a}}$ & $1.67^{\mathrm{a}}$ \\
\hline Polyethylene Plastic & $0.71^{\mathrm{b}}$ & $1.55^{\mathrm{b}}$ \\
\hline $\mathrm{SEm}( \pm)$ & 0.03 & 0.034 \\
\hline $\operatorname{LSD}_{(0.05)}$ & $0.08^{* *}$ & $0.08^{*}$ \\
\hline $\mathrm{CV}(\%)$ & 14.944 & 7.24 \\
\hline Grand Mean & 0.781 & 1.612 \\
\hline
\end{tabular}

\section{Average number of leaves}

At the final observation, Allison variety showed the highest number of leaves per sapling (9.20) and the minimum data was recorded in Monty Variety (6.25). This higher number of leaves of grafted scion may increase the rate of photosynthesis, and hence increase growth. The varietal character shows differentiated translocation of food materials which also enhances excellent flashing of new leaves (Bose \& Howlader, 2018).

Scion tied with grafting tape showed higher number of leaves (8.49) than polyethylene plastic (6.94). The significant result at last two observations might be due to better bud growth and increment in the number of sprouted buds per grafts in grafting tape which subsequently results in higher number of leaves. The elasticity of grafting tape prevent humidity loss and drying of bud sticks, wound tissue over the cut surfaces could be produced more easily for healing (Zenginbal, 2006). 
Journal of Agriculture and Natural Resources (2019) 2(1): 180-192

ISSN: 2661-6270 (Print), ISSN: 2661-6289 (Online)

DOI: https://doi.org/10.3126/janr.v2i1.26065

There was no significant difference in the interaction effect of scion variety and wrapping materials at any observation.

Table 5: Effect of scion variety and wrapping materials on average number of leaves at Dolakha, Nepal 2019

\begin{tabular}{lccccc}
\hline \multirow{2}{*}{ Treatments } & \multicolumn{5}{c}{ Average number of leaves } \\
\cline { 2 - 6 } & 70 DAG & 85 DAG & 100 DAG & 115 DAG & 130 DAG \\
\hline Scion Variety & & & & & \\
Monty & $1.521^{\mathrm{a}}$ & $2.92^{\mathrm{b}}$ & $3.937^{\mathrm{b}}$ & $5.17^{\mathrm{b}}$ & $6.25^{\mathrm{c}}$ \\
Bruno & $1.728^{\mathrm{a}}$ & $4.16^{\mathrm{a}}$ & $5.318^{\mathrm{a}}$ & $6.63^{\mathrm{a}}$ & $7.94^{\mathrm{b}}$ \\
Hayward & $0.93^{\mathrm{b}}$ & $2.74^{\mathrm{b}}$ & $4.8^{\mathrm{ab}}$ & $6.34^{\mathrm{a}}$ & $7.46^{\mathrm{bc}}$ \\
Allison & $1.81^{\mathrm{a}}$ & $3.57^{\mathrm{ab}}$ & $5.89^{\mathrm{a}}$ & $7.01^{\mathrm{a}}$ & $9.20^{\mathrm{a}}$ \\
\hline SEm( \pm$)$ & 0.197 & 0.27 & 0.4 & 0.36 & 0.55 \\
LSD $(0.05)$ & $0.58^{*}$ & $0.816^{* *}$ & $1.2^{*}$ & $1.06^{*}$ & $1.62^{* *}$ \\
\hline Wrapping material & & & & & \\
Grafting tape & 1.65 & 3.43 & 5.37 & $6.78^{\mathrm{a}}$ & $8.49^{\mathrm{a}}$ \\
Polyethylene plastic & 1.34 & 3.26 & 4.59 & $5.78^{\mathrm{b}}$ & $6.94^{\mathrm{b}}$ \\
\hline SEm( \pm$)$ & 0.14 & 0.196 & 0.28 & 0.25 & 0.39 \\
LSD $(0.05)$ & $0.41 \mathrm{~ns}$ & $0.578 \mathrm{~ns}$ & $0.85 \mathrm{~ns}$ & $0.75^{*}$ & $1.15^{*}$ \\
\hline CV $(\%)$ & 37.1 & 23.4 & 23.1 & 16.2 & 20.2 \\
Grand Mean & 1.5 & 3.35 & 4.99 & 6.29 & 7.72 \\
\hline
\end{tabular}

Means followed by common letter(s) within columns are non-significantly different based on DMRT at $\mathrm{P}=0.05$, ** significant at 0.01 P level, *** significant at 0.001 level, SEM: Standard error of mean, CV: Coefficient of Variance

\section{Percentage of graft success and survived grafts}

Graft success is the total number of successful grafts over total number of grafts per plot at the final observation. Successful grafts were those which had sprouted scion; un-sprouted and dead scions were considered as the failure grafts. The effect of different scion variety on graft success was found significant at the final observation at 130 DAG. Allison variety gave the highest graft success $(96.87 \%)$ which was statistically at par with Hayward and Bruno. The lowest was recorded from Monty $(73.43 \%)$. Survived grafts are those saleable grafts obtained excluding the dead graft and the mortality of sprouted grafts. The highest percentage of survived grafts was obtained in Allison variety (93.75\%) statistically similar with Hayward (86.75\%) and Bruno (85.49\%) and the lowest survival was seen in Monty (64.21\%). The varietal character matched up with the prevailing atmospheric condition in Allison variety and lead to the less number of un-sprouted grafts and mortality of grafts after sprouting leading to higher graft success. Hayward showed late sprouting but after the fulfillment of chilling period, it also showed significantly higher success percentage. The lowest success percentage observed in Monty was due to higher dead grafts and mortality of sprouted grafts which might be due to unsuitable climatic conditions for graft success leading to graft incompatibility. Hartmann et al. 2007) reported that genetic factors had a significant effect on grafting success. The ability of two kinds of plant to form a successful graft union is largely based on their natural relationship(Sharma, 2002). 
Journal of Agriculture and Natural Resources (2019) 2(1): 180-192

ISSN: 2661-6270 (Print), ISSN: 2661-6289 (Online)

DOI: https://doi.org/10.3126/janr.v2i1.26065

Table 6: Effect of Scion variety and wrapping materials on percentage of graft success and survival percentage in Dolakha, Nepal 2019

\begin{tabular}{|c|c|c|}
\hline Treatments & Graft success $(\%)$ & Survived grafts $(\%)$ \\
\hline \multicolumn{3}{|l|}{ Scion Variety } \\
\hline Monty & $73.437^{\mathrm{b}}$ & $64.212^{\mathrm{b}}$ \\
\hline Bruno & $92.187^{\mathrm{a}}$ & $85.49^{\mathrm{a}}$ \\
\hline Hayward & $92.187^{\mathrm{a}}$ & $86.76^{\mathrm{a}}$ \\
\hline Allison & $96.875^{\mathrm{a}}$ & $93.75^{\mathrm{a}}$ \\
\hline $\operatorname{SEm}( \pm)$ & 2.53 & 3.24 \\
\hline $\operatorname{LSD}_{(0.05)}$ & $7.45^{* * *}$ & $9.53^{* * * *}$ \\
\hline \multicolumn{3}{|l|}{ Wrapping Materials } \\
\hline Grafting Tape & $92.187^{\mathrm{a}}$ & $87.01^{\mathrm{a}}$ \\
\hline Polyethylene Plastic & $85.156^{\mathrm{b}}$ & $78.08^{\mathrm{b}}$ \\
\hline $\operatorname{SEm}( \pm)$ & 1.79 & 2.29 \\
\hline $\operatorname{LSD}_{(0.05)}$ & $5.27^{*}$ & $6.74^{*}$ \\
\hline $\mathrm{CV}(\%)$ & 8.08 & 11.1 \\
\hline Grand Mean & 88.7 & 82.6 \\
\hline \multicolumn{3}{|c|}{$\begin{array}{l}\text { Means followed by common letter }(s) \text { within columns are non-significantly different based on DMRT at } P=0.05 \text {, } \\
* * \text { significant at } 0.01 \text { P level, } * * * \text { significant at } 0.001 \text { level, SEM: Standard error of mean, CV: Coefficient of } \\
\text { Variance }\end{array}$} \\
\hline \multicolumn{3}{|c|}{$\begin{array}{l}\text { The effect of wrapping materials on success also gave the significant result. Tying the graft } \\
\text { union with grafting tape gave the significantly higher graft success }(92.18 \%) \text { and survival } \\
\text { percentage }(87.01 \%) \text { but the grafted rootstock tied with normal plastic recorded significantly } \\
\text { lower graft success }(85.15 \%) \text { and survival percentage }(78.08 \%) \text {. The lowest success rate in } \\
\text { polyethylene plastic might be due to less tight cambial binding which adversely affected its } \\
\text { differentiation to form vascular cambium and associated vascular system and led to } \\
\text { comparatively higher death. This may be because the polyethylene plastic did not provide a } \\
\text { waterproof barrier, which Lipetz (1970) suggested may be a prerequisite for wound healing } \\
\text { Grafting tape can be stretched over the whole graft union for a complete cover, and it acts as } \\
\text { a mechanical barrier preventing the scion from drying out, hence improve grafting survival } \\
\text { Furthermore, it allows for easy and rapid application. The result was in conformity with } \\
\text { Zhang \& Hao (2015). }\end{array}$} \\
\hline
\end{tabular}


Journal of Agriculture and Natural Resources (2019) 2(1): 180-192

ISSN: 2661-6270 (Print), ISSN: 2661-6289 (Online)

DOI: https://doi.org/10.3126/janr.v2i1.26065

Percentage of dead grafts after sprouting:

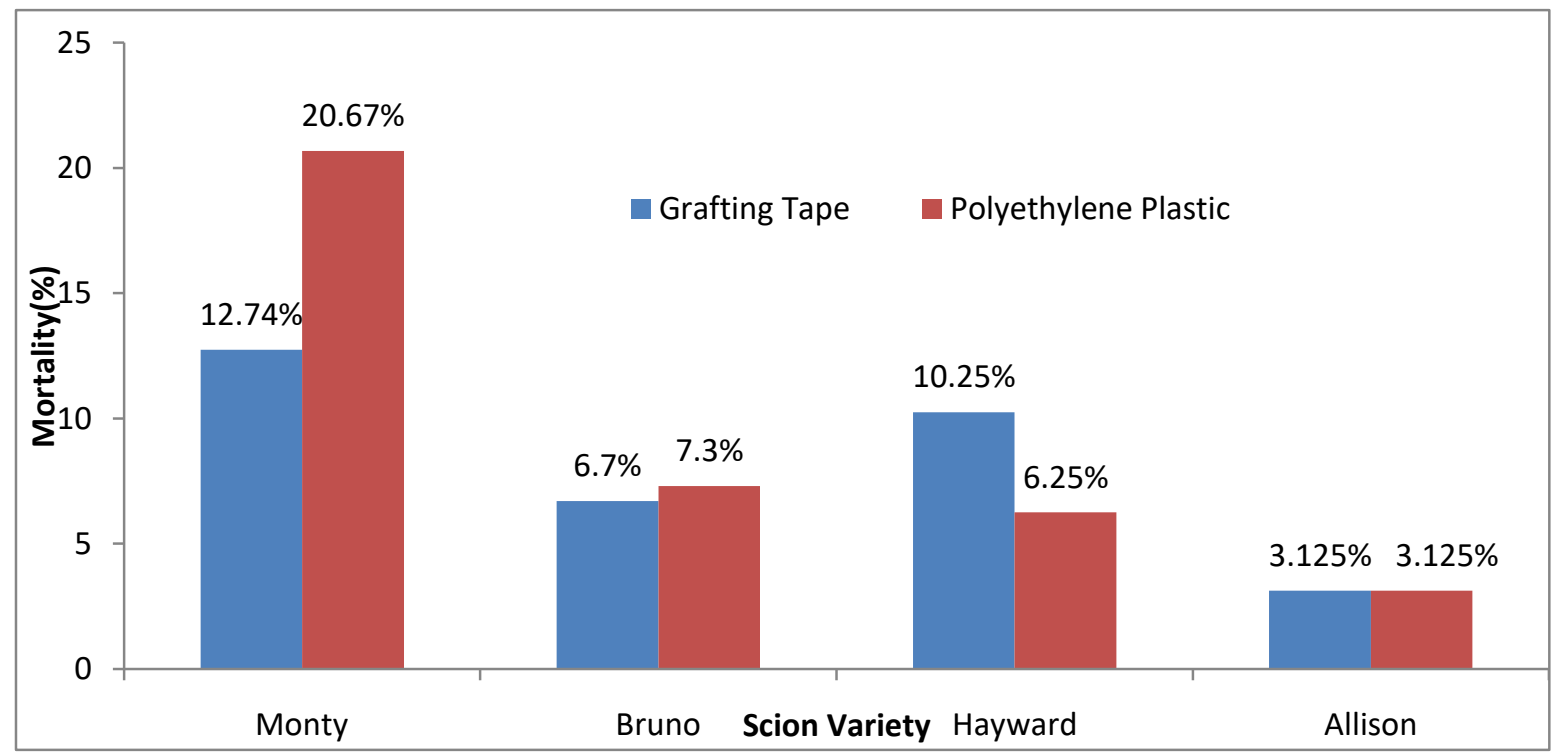

Figure 2: Percentage of dead grafts after sprouting

The highest mortality was obtained in Monty variety (16.70\%) while the lowest was seen in Allison variety $(3.12 \%)$ at the final observation. The prevailing temperature and humidity might not be optimum for Monty variety which could not ensure better movement of water and nutrients towards leaves and photosynthates away from the leaves leading to higher death of the sprouts.

\section{CONCLUSION}

Based on the result of this experiment, Allison variety was the superior variety in terms of graft success and other growth parameters under the climatic condition of Dolakha and grafting tape was better than locally used polyethylene plastic due to its tight cambial binding.

\section{.ACKNOWLEDGEMENTS}

The fund and technical support for carrying out this research was provided by Prime Minister Agriculture Modernization Project and Agriculture and Forestry University, Rampur, Chitwan, Nepal. The authors also acknowledge Temperate Fruits Rootstock Development Centre, Boch, Dolakha for giving access to experimental plot and materials.

\section{Author Contributions}

D.P., M.S., S.B., planned, designed, performed experiments and performed the analysis. B.S. was involved in planning and supervision of the work and interpretation of the result.

\section{Conflict of Interest}

The authors declare that there is no conflict of interest regarding the publication of this paper. 
Journal of Agriculture and Natural Resources (2019) 2(1): 180-192

ISSN: 2661-6270 (Print), ISSN: 2661-6289 (Online)

DOI: https://doi.org/10.3126/janr.v2i1.26065

\section{REFERENCES}

Bose, S. K., Ghosh, K., \& Howlader, P. (2019). Effect of Variety and Rootstock Age on the Success and Survivability of Epicotyl Grafting in Mango. Journal of Agricultural Research Advances , 13-25.

Crowhurst, N., Whittaker, D., \& Gardner, R. (1992). The Genetic Origin of Kiwifruit. Acta Horticulturae, 61-62.

Dhakal, S. P. (2018). An introduction of Kiwifruit and Cultivation Technology. Charikot, Nepal: Temperate fruits rootstock development centre.

FAOSTAT (2013/2014). Retrieved from Food and Agriculture Organization of the United states: http://faostat.fao.org/

Gomez, K.A., \& Gomez, A.A. (1984). Statistical procedures for agricultural research. $2^{\text {nd }}$ ed., International Rice Research Institute, College, Laguna, 680p

Gotame, T. P., Gautam, I. P., Subedi, G., Dhakal, M., \& Sapkota, S. (2016). Kiwifruit Production Technology. Lalitpur, Nepal: Nepal Agricultural Research Council, Horticulture Research Division

Hartmann, H. T., Kester, D. E., Davies, F. T., \& Geneve, R. L. (2007). Plant Propagation Principles and Practices. New Delhi, India: Prentice Hall Pvt.Ltd.

Jan, M. T., Shah, P., Hollington, P. A., Khan, M. J., \& Sohail, Q. (2009). Agriculture research: Design and analysis. A monograph. Peshawar Agricultural University

Kandel, M., \& Shrestha J. (2019). Genotype x environment interaction and stability for grain yield and yield attributing traits of buckwheat (Fagopyrum tataricum Geartn). Syrian Journal of Agricultural Research, 6(3), 466-476.

Lipetz, J. (1970). Wound Healing in Higher Plants. International Review of Cytology 27, 128.

MOAD. (2016/17). Statistical Information on Nepalese Agriculture. Singha Durbar Kathmandu, Nepal: Monitoring, Evaluation and Statistics Division, Government of Nepal.

Mohammadi, J., \& Abdi Senehkouhi, M. (1993). Kiwifruit Cultivation. Tehran, Iran: Farhang-e Jame Press.

Morton, F. J. (2004). Fruits of Warm Climate. Miami:Creative Resorce System Inc.

Pope, T. E., \& McFadden, S. E. (1960). Preliminary Comparison of Wrapping Materials in Grafting Pecans. Florida state Horticultural Society, 332-334.

Richardson, D. P., Ansell, J., \& Drummond, L. N. (2018). The Nutritional and Health Attributes of Kiwifruit: a Review. European Journal of Nutrition, 57, 2659-2676

Sharma, H.P., Dhakal, K.H., Kharel, R., \& Shrestha, J. (2016). Estimation of heterosis in yield and yield attributing traits in single cross hybrids of maize. Journal of Maize Research and Development, 2(1), 123-132, doi: http://dx.doi.org/10.3126/jmrd.v2i1.16223

Sharma, R. R. (2002). Propagation of Horticultural Crops: Principles and Practices. Ludhiana, India: Kalyani Publishers.

Shrestha, J. (2019). P-Value: A true test of significance in agricultural research. Retrieved from https://www.linkedin.com/pulse/p-value-test-significance-agricultural-researchjiban-shresthal 
Journal of Agriculture and Natural Resources (2019) 2(1): 180-192

ISSN: 2661-6270 (Print), ISSN: 2661-6289 (Online)

DOI: https://doi.org/10.3126/janr.v2i1.26065

Sims, B. J. (2011). Rooting Evaluation of Kiwifruit (Actinidia chinensis) and Effects of Anaerobiosis on Bud Break(Master's thesis). Auburn University, Auburn, Alabama. Syamal, M., Maurya, V., \& Joshi, M. (2013). Effect of Method and Time of Propagation in Bael Under Different Growing Condition. Indian Journal of Horticulture, 70, 127-129

Zenginbal, H.,Celik H., \& Ozcan, M. (2006). The Effect of Tying and Wrapping Materials and Their Color on Budding Success in Kiwifruit. Turkish Journal of Agriculture and Forestry, 30(1), 119-124.

Zhang, R., \& Hao, M. (2015). Evaluation of Epicotyl Grafting on 22 to 55 day old Pecan. Hort Technology, 25(3), 392-396. 